\title{
Literature Review of the Study of Carbon Emission Rights
}

\author{
Huan Peng*, Rui Jiang, Chaobo Zhou \\ School of Economics and Finance, Chongqing University of Technology, Chongqing, China \\ Email: ^penghuan@cqut.edu.cn, jiangrui@cqut.edu.cn, zhouchaobo@.cqut.edu.cn
}

How to cite this paper: Peng, H., Jiang, R. and Zhou, C.B. (2017) Literature Review of the Study of Carbon Emission Rights. Low Carbon Economy, 8, 133-138. https://doi.org/10.4236/lce.2017.84011

Received: November 22, 2017 Accepted: December 24, 2017 Published: December 27, 2017

Copyright $\odot 2017$ by authors and Scientific Research Publishing Inc. This work is licensed under the Creative Commons Attribution International License (CC BY 4.0).

http://creativecommons.org/licenses/by/4.0/

\begin{abstract}
The importance of green development, namely environment-friendly development is recognized world wild today. As integral parts of green development, carbon finance and carbon trading are expected to have huge market potential, which justifies the academic significance of a literature study in this area. The study of trading of the carbon emission rights mainly focuses on the following three aspects: the classification of carbon emission rights, the influencing factors of carbon emission rights and the price features of carbon emission rights.
\end{abstract}

\section{Keywords}

Carbon Emission, Carbon Emission Rights, Financial Asset

\section{The Classification of Carbon Emission Rights}

Carbon emission rights originated from pollutant emission rights. American economist Dales first proposed pollutant emission right, which allows firms to emit pollutants to the environment by following legal regulations. The rights become tradable if government allows it to be traded among firms.

IFRIC3 (International Financial Reporting Interpretations Committee 3Emission Rights) explains emission right as

Typically in cap and trade schemes, a government (or government agency) issues rights (allowances) to participating entities to emit a specified level of emissions. (The government may issue the allowances free of charge or the participant may be required to pay for them). Participants in the scheme are able to buy and sell allowances and therefore, in many schemes, there is an active market for the allowances. At the end of a specified period, participants are required to deliver allowances equal to their actual emissions [1]. 
Kyoto Protocol advises countries to deal with the greenhouse gases (GHG) reduction issue through market mechanism. GHG emission rights, namely carbon emission rights are regarded as tradable goods, which are usually obtained through government allocation and market purchasing. There are three different views regarding the financial classification of carbon emission rights.

The first view is to classify carbon emission rights as stock goods. Federal Energy Regulatory Commission (FERC) requires that the classification of carbon emission rights should be based on their usage of corporate [2]. If the rights are used to compensate the GHG emission, they should be recorded as stock goods. Mortand Milne [3] [4] argued that carbon emission rights should meet the preconditions to be considered as stock goods. The Mouvement des entreprises de France (MEDEF), or the Movement of the Enterprises of France, also claimed that carbon emission rights had the features of stock goods. However, stock goods are usually tangible goods. The ultimate purpose of owning stock goods is to sell them. Being a type of rights, carbon emission rights are not comparable to stock goods in nature.

The second view is to classify carbon emission rights as intangible goods. Since carbon emission rights are either obtained through free government allocation or purchasing and are expected to generate economic revenue, which makes them a type of intangible asset. After extensive consultation, International Financial Reporting Interpretations Committee (IFRIC 2003) concluded that carbon emission rights should be confirmed as intangible assets and accounted by the fair value measurement. (IFRIC3) issued by International Accounting Standards Board (IASB) (2004) proscribes that carbon emission rights should be defined as assets with no physical form, thus should be treated as intangible assets. However, intangible assets refer to identifiable non-monetary intangible assets owned by or under the control of firms. The concept of carbon emission rights is raised from the perspective of natural environment, instead of business firms, so it is questionable to treat these rights as intangible assets.

The third view is to classify carbon emission rights as financial assets. The US property law considers carbon emission rights as financial derivatives and allows them to be deposited in banks as securities. FRS13 issued by Accounting Standard Board in 1998 proposed that carbon-trading contracts should be considered as financial derivatives. Being an embedded derivative, the price of carbon emission rights are determined by market factors external to the firms directly involved in their trading. It should be noted that the presence of financial assets needs a well-developed financial market. However, the activity of the secondary carbon emission trading market is not only related to the supply of demand among firms, but also to the carbon emission regulations in the primary market. Therefore, should carbon emission rights be treated as financial assets or not is determined by their trading environment. With the development of the three big exchange markets, carbon emission rights present themselves as a type of financial assets and are studied by scholars with 
the methods applied to financial assets.

\section{Study of the Price Influencing Factors of Carbon Emission Rights}

Classical economic theory holds that market price is a reflection of and fluctuates around commodity value. In a well-developed international carbon emission exchange market, the price of emission rights reveals their real value pretty well. The study of the price of carbon emission rights focuses on the pricing influencing factors. Future study on the trend, distribution and fluctuation of the price using economic models will have great significance. Therefore, upon the establishment and perfection of the carbon emission exchange market, scholars in the world have been analyzing the price influencing factors and concluded the major influencing factors are government policy, weather and energy prices. Government quotas determine the supply of rights and are key influencing factors of the price. Inter-temporal reserve system also affects the supply of carbon emission rights. Denying inter-temporal reserve system will nullify unused current rights and reduce total supply. Daskalaki et al. [5] found that prohibition of inter-temporal reserve system and lending would heavily influence the price of carbon emission rights. Chevallier [6] studied the 2005-2008 EUA price behavior of EUETS and concluded that the main cause for price fluctuation was market mechanism rather than the speculation of investors. Chen and Wang [7] studied the influence of supply and demand on the price of carbon emission rights and concluded government policies had the biggest impact as well. Weather change will affect the demand for fossil fuel and thus the demand and price for carbon emission rights. Cold weather leads to increased fossil fuel consumption and carbon emission to push up the price of emission rights and visa versa. Maria et al. [8] studied the influence of weather on the price of carbon emission right empirically, and found an obvious positive correlation between the two. Alberola et al. [9] found that hot weather had no obvious influence on the price of emission rights while extreme cold weather exerted a significant influence.

Energy price is another influencing factor for the price of carbon emission rights. The relative price change of different energy types causes demand change and the absolute price change causes change in total energy consumption. The two kinds of price change lead to change in carbon emission demand and price. Hintermann [10] discovered a negative correlation between the price of carbon emission rights and hydroelectric power generation in Europe. Rickels et al. [11] found increased wind speed would cause EUA price drops. Gronwald et al. [12] studied the connection of the price of carbon emission rights with commodity prices and the macroeconomic environment with a copula model and discovered a significant positive correlation between EUA price and energy price such as that of coal and electricity, no correlation between EUA price and crude oil price, and a huge impact by macroeconomic environment development. With a regression model, Hammoudeh et al. [13] found that the price of carbon emis- 
sion price was positively correlated with electricity price and negatively correlated with crude oil, while gas price mainly demonstrated a negative influence on the price of carbon emission rights but also a positive one on the latter when the gas price was very low.

\section{Study of the Price Features of Carbon Emission Rights}

Value study of carbon emission rights by foreign scholars has mostly been related to pricing. Due to the highly financialized trading process and the availability of transaction data, these studies usually adopt the empirical approach by using regression models, and compare the results with real market prices to get the more efficient study methods.

The GARCH model proposed by Bollerslev [14] based on ARCH is the most frequently used regression model. Luca [15] used GARCH to model the carbon emission rights market in Europe and the US and found the data of the emerging carbon trading market changed so quickly that it was impossible to predict risk levels by models at a specific time point. He suggested giving different weights to prices of different time points to predict risk levels with the GARCH model. Paolellas and Taschini [16] advocated the use of new GARCH model to study the variance dynamics of EUAs. With the use of parameters with various weights and likelihood function, the ability to predict short-term positive and negative returns could be improved. Benz and Truck [17] studied the spot prices of carbon emission rights in EU ETS and concluded that different trading terms caused different return rate volatility patterns.

Normal non-Gaussian and Brown Movement are also applied to study the price of carbon emission rights. Seifert et al. [18] studied the dynamic movement of carbon emission price and found no regular movement pattern with respect to time. Partial differentiation equations can be used to depict the price change but is not widely applicable in practice. Very few occasions justify the application of partial differentiation. Gorecki et al. [19] found normal non-Gaussian model to be an efficient model in EUAs price study after analyzing options of the European carbon emission rights. Skipping and non-stationary are both features of carbon credits and can be estimated by expanded Geometric Brown Movement. Frunza et al. [20] studied the price data between January 2006 and March 2009 with Brown Movement and NIG distribution and concluded that NIG could be used to study the price of carbon emission rights in EU. Through these researches, it's not hard to see that the price of carbon emission rights is very volatile even in such mature markets. Zhu [21] applied EMD (Empirical Mode Decomposition) to analyze the trading of carbon emission rights in Europe and decomposed the price into eight IMFs (Intrinsic Mode Functions) and an error. He then restructured the IMPs and error into high frequency component, low frequency component and trend component with hierarchical clustering. The three components stand for short-term market volatility, major trend mutation and long-term trend. A strategy to predict price was then proposed 
based on his analysis. Due to the price instability, it is extremely difficult to predict the return and volatility rates with a single model. Different models are needed for prices of different time periods, multiple models are necessary for a more precise prediction of expected prices.

\section{Conclusions}

Based on the previous literature review, this paper concludes that the study of the classification of carbon emission trading, the price features and the price-influencing factors in the trading market has been comprehensive and insightful, and recommends three fields for futures study: 1) The valuation of carbon emission rights from the perspective of real option. 2) Innovation in derivatives of carbon emission rights. 3) The establishment of a global carbon emission trading market and the price connection between this global market and regional markets.

\section{References}

[1] Bradbury, M. (2007) An Anatomy of an IFRIC Interpretation. Accounting in Europe, 4, 109-122. https://doi.org/10.1080/17449480701727890

[2] Federal Power Commission (1973) Uniform System of Accounts Prescribed for Public Utilities and Licensees.

[3] Dittenhofer, M. (1995) Environmental Accounting and Auditing. Managerial Auditing Journal, 10, 40-51. https://doi.org/10.1108/02686909510093615

[4] Milne, M.J. (1996) Capitalizing and Appropriating Society's Rights to Clean Air: A Comment on Wambsganss \& Sanford's Accounting Proposal. Critical Perspectives on Accounting, 7, 681-695. https://doi.org/10.1006/cpac.1996.0079

[5] Daskalakis, G., Psychoyios, D. and Markellos, R.N. (2009) Modeling $\mathrm{CO}_{2}$, Emission Allowance Prices and Derivatives: Evidence from the European Trading Scheme. Journal of Banking \& Finance, 33, 1230-1241. https://doi.org/10.1016/j.jbankfin.2009.01.001

[6] Chevallier, J. (2011) Detecting Instability in the Volatility of Carbon Prices. Energy, 33, 99-110. https://doi.org/10.1016/j.eneco.2010.09.006

[7] Chen, X.H. and Wang, Z. (2012) Empirical Research on Price Mechanism of European Carbon Emissions Trading. Science \& Technology Progress \& Policy, 27, 142-147.

[8] Mansanet-Bataller, M., Pardo, A. and Valor, E. (2007) $\mathrm{CO}_{2}$ Prices, Energy and Weather. Energy Journal, 28, 73-92. https://doi.org/10.5547/ISSN0195-6574-EJ-Vol28-No3-5

[9] Alberola, E., Chevallier, J. and Chèze, B. (2008) The EU Emissions Trading Scheme: Disentangling the Effects of Industrial Production and $\mathrm{CO}_{2}$ Emissions on Carbon Prices. Social Science Electronic Publishing, 116, 93-126.

[10] Hintermann, B. (2010) Allowance Price Drivers in the First Phase of the EU ETS. Journal of Environmental Economics \& Management, 59, 43-56. https://doi.org/10.1016/j.jeem.2009.07.002

[11] Rickels, W., Görlich, D. and Peterson, S. (2015) Explaining European Emission Allowance Price Dynamics: Evidence from Phase II. German Economic Review, 16, 181-202. https://doi.org/10.1111/geer.12045 
[12] Gronwald, M., Ketterer, J. and Trück, S. (2011) The Relationship between Carbon, Commodity and Financial Markets: A Copula Analysis. Economic Record, 87, Supplement S1, 105-124. https://doi.org/10.1111/j.1475-4932.2011.00748.x

[13] Hammoudeh, S., Nguyen, D.K. and Sousa, R.M. (2014) Energy Prices and $\mathrm{CO}_{2}$, Emission Allowance Prices: A Quantile Regression Approach. Energy Policy, 70, 201-206. https://doi.org/10.1016/j.enpol.2014.03.026

[14] Bollerslev, T. and Ghysels, E. (1996) Periodic Autoregressive Conditional Heteroscedasticity. Journal of Business \& Economic Statistics, 14, 139-151.

[15] Taschini, L. and Marc, S. (2008) An Econometric Analysis of Emission Allowance Prices. Journal of Banking \& Finance, 32, 2022-2032. https://doi.org/10.1016/j.jbankfin.2007.09.024

[16] Paolella, M.S. and Taschini, L. (2008) An Econometric Analysis of Emission Allowance Prices. Journal of Banking \& Finance, 32, 2022-2032. https://doi.org/10.1016/j.jbankfin.2007.09.024

[17] Benz, E. and Trueck, S. (2006) $\mathrm{CO}_{2}$ Emission Allowances Trading in Europe-Specifying a New Class of Assets. Investment Management \& Financial Innovations, 4, 30-40.

[18] Seifert, J., Uhrig-Homburg, M. and Wagner, M. (2008) Dynamic Behavior of $\mathrm{CO}_{2}$, Spot Prices. Journal of Environmental Economics \& Management, 56, 180-194. https://doi.org/10.1016/j.jeem.2008.03.003

[19] Gorecki, P.K., Lyons, S. and Tol, R.S.J. (2010) EU Climate Change Policy 2013-2020: Using the Clean Development Mechanism More Effectively in the Non-EU-ETS Sector. Energy Policy, 38, 7466-7475. https://doi.org/10.1016/j.enpol.2010.08.033

[20] Frunza, M.C. and Lassoudière, A. (2010) Dynamic Factor Analysis of Carbon Allowances Prices: From Classic Arbitrage Pricing Theory to Switching Regimes. Documents de travail du Centre d'Economie de la Sorbonne 2010.62 - ISSN: 1955-611X.

[21] Zhu, B.Z. (2015) Carbon Price Analysis Using Empirical Mode Decomposition. Computational Economics, 45, 195-206. https://doi.org/10.1007/s10614-013-9417-4 